Sarah Polkinghorne

University of Alberta, Edmonton, Alberta, Canada

Swinburne University of Technology, Melbourne, Australia

\author{
Heidi Julien \\ State University of New York at Buffalo, Buffalo, New York, USA
}

\title{
Against the Wind: Challenges and Barriers to Canadian Academic Librarians' Instructional Practices (Paper)
}

\begin{abstract}
Helping students learn how to navigate information - and misinformation - is as important as ever. The Canadian information literacy (IL) landscape continues to evolve along with rhetorical, theoretical, and contextual developments, such as the new Framework for Information Literacy for Higher Education and the critical library pedagogy movement. However, relatively little is known about actual changes to librarians' IL practices over time, and what causes or prevents librarians to change their practices. This paper shares results from a twenty-year study of IL practices in Canadian academic libraries, with a focus on the barriers and challenges to this work.

\section{Résumé}

Do we really live in a "post-truth" era? Are citizens truly unable to distinguish fact from fiction in the news they follow? Developing the skills to find and evaluate information is now perhaps more important than ever. Very often, it lies to librarians to raise awareness of this skill set, i.e., information literacy, among students in the post-secondary context. High-quality information literacy (IL) instruction remains critical to help students succeed academically, and to sensitize these nascent citizens to the importance of identifying reliable information in the sea of misinformation and disinformation in which we all find ourselves.

The past several years have brought noteworthy changes to the IL landscape in Canada. Specific examples of these changes are readily available. The Framework for Information Literacy for Higher Education was officially endorsed by the Association of College and Research Libraries (ACRL) in January 2016, codifying a shift away from skills-focused 
IL toward a more flexible, conceptual, contextual approach (ACRL, 2015). The ACRL made another change in June 2016 when its board of directors formally rescinded the Information Literacy Competency Standards for Higher Education, on which librarians have based many IL programs over the past 16 years (“ACRL Board takes action," 2016). Meanwhile, some librarians have begun developing a critical pedagogy for IL, first by meeting for structured discussions virtually on Twitter and eventually by organizing dedicated workshops and publications (Farkas, 2017; Pagowsky and McElroy, 2016). In the larger system of higher education within which academic libraries and IL instruction exist, recent years have seen significant changes around technology in learning, the use of metrics, and labour casualization, to name just a few.

We can point out rhetorical, theoretical, and contextual changes such as these fairly easily. But much less is known about actual changes to practice, about whether or not, or how, information literacy instruction practices are changing over time within Canadian academic libraries. This gap matters because without a current picture of IL practices, we cannot understand these practices and what affects them. This is the gap addressed by our study.

This paper shares results from a longitudinal study of IL practices in Canadian academic libraries. This study stretches back over twenty years (Julien, 2000; Julien, 2005; Julien and Leckie, 1997; Julien, Tan, and Merillat, 2013) and is the only one of its kind in Canada. The purpose of this study is to document instructional practices in Canadian college and university libraries in order to enable evidence-based understanding and change.

The presentation will focus on results from the fifth and most recent national survey of Canadian college and university librarians, conducted in late 2016 and early 2017. Ethics approval for the study was obtained from the University of Alberta Research Ethics Board. Links to English and French versions of this online survey were posted to librarians' listservs in Canada, and academic librarians with instructional responsibilities were invited to participate. At the time of this submission, the survey has not yet closed. The data will be analyzed quantitatively and qualitatively; content analysis will be used to analyze open-ended responses and comments (Julien, 2008). In this CAIS/ACSI presentation we will share a rigorous current picture of IL practices in Canada, with a focus on the barriers and challenges to this work. Historically, the longitudinal survey results show that challenges have focused on limited resources (financial, physical, time pressures), on complex campus politics and relationships, and on students' narrow understanding of the value of information literacy and of librarians. The latest survey results will be compared with data from the previous surveys to paint a picture of current and historical barriers and challenges facing instructional librarians as they seek to inculcate a critical skill set in a social context that demands urgent response. 
The value of this research, in addition to documenting professional practice over time, lies in the opportunities it uncovers. Library administrators can use these data on current professional practice to identify ways to ameliorate the barriers and challenges identified, through staff training, resource allocation, and advocacy, on- and off-campus.

Instructional librarians themselves can place their own professional challenges in context, by comparing their personal experiences with those of their peers and finding starting points for mutual support and collective action. Librarians and researchers committed to breaking new ground in information literacy work, such as those theorizing critical library pedagogy, can gain from these data a sense of what could be necessary in order to change practices on a wide scale. Students of librarianship can also use the data to inform their preparation for professional work.

This paper, with its longitudinal approach, connects with the conference theme of building on past research. Longitudinal work is rare in LIS, giving this paper a connection to the conference theme of diversifying methods within the discipline. The paper also connects with the theme of connecting perspectives and identities, as the research explores the identities of instructional librarians as they navigate their professional obligations in relation to institutional constraints.

\section{References}

ACRL Board takes action on information literacy standards (2016, June 25). ACRL Insider. Retrieved from http://www.acrl.ala.org/acrlinsider/archives/12126

Association of College \& Research Libraries (ACRL). (2015). Framework for Information Literacy for Higher Education. Retrieved from http://www.ala.org/acrl/standards/ilframework

Farkas, M. (2017, January 3). Never neutral: critical librarianship and technology. American Libraries, 48(1/2). Retrieved from https://americanlibrariesmagazine.org/2017/01/03/never-neutral-critlib-technology

Julien, H. (2000). Information literacy instruction in Canadian academic libraries: Longitudinal trends and international comparisons. College \& Research Libraries, 61(6), 510-523.

Julien, H. (2005). A longitudinal analysis of information literacy instruction in Canadian academic libraries. Canadian Journal of Information and Library Science, 29(3), 289-313.

Julien, H. (2008). Content analysis. In Given, L. (Ed.), SAGE encyclopedia of qualitative research methods (120-22). Los Angeles: Sage. 
Julien, H., \& Leckie, G. (1997). Bibliographic instruction trends in Canadian academic libraries. Canadian Journal of Information and Library Science, 22(2), 1-15.

Julien, H., Tan, M., \& Merillat, S. (2013). Instruction for information literacy in Canadian academic libraries: A longitudinal analysis of aims, methods, and success. Canadian Journal of Information and Library Science, 37(2), 81-102.

Pagowsky, N., \& McElroy, K. (Eds.) (2016). Critical library pedagogy handbook (Vols. 1-2). Chicago: American Library Association. 